\title{
Niels Kofoed in memoriam
}

\author{
K.E. Bugge
}

I september 2016 døde Niels Kofoed. Vedrørende hans biografi oplyser en omslagstekst på en af hans udgivelser følgende: Hans fulde navn - som han sjældent brugte - var Niels Vilhelm Kofoed. Han var født i København og student fra Christianshavn Gymnasium. Om hans akademiske løbebane meddeles, at han var cand.mag. fra Københavns Universitet med fagene dansk og fransk og dr.phil. på en afhandling om H.C. Andersens fortællekunst. Om Kofoeds ansættelser oplyses, at han i 1955-57 var rejselektor for Foreningen Norden, i 1957-62 lektor i dansk ved Stockholms Universitet og i 1962-65 ved Lunds Universitet. Fra 1965-1970 var han først ansat ved Aarhus Universitet, dernæst ved Odense Universitet. I 1971-72 var han professor i nordisk sprog og litteratur ved University of Washington [i Seattle]. Fra 1974 og fremefter var han studielektor ved Københavns Dag- og Aftenseminarium.

At Kofoed inden for sit danskstudium valgte at skrive om Grundtvig, var ikke tilfældigt. I den akademiske verden kunne man netop på dette tidspunkt konstatere en ny opmærksomhed over for Grundtvig og hans forfatterskab. I 1948 udkom den første af det nystiftede Grundtvig-Selskabs årbøger. Større offentlig opmærksomhed vakte Henning Høirups og Helge Toldbergs Grundtvigdisputatser, der udkom henholdsvis i 1949 og 1950. Disse udgivelser inspirerede både ældre og især yngre til at gå ombord i Grundtvig. På universiteterne i København og Århus var i årene omkring 1950 flere studerende under vejledning af professorerne Hal Koch og P.G. Lindhardt gået i gang med at skrive speciale om Grundtvig. For sit vedkommende blev Kofoed inspireret af professor i dansk litteratur Ejnar Thomsen, som netop på dette tidspunkt arbejdede med Grundtvigs forfatterskab (jf. den udførlige anmeldelse af Toldbergs disputats i 
Grundtvig-Studier 1952). I årene omkring 1950 var søgelyset - både inden for teologi og inden for litteraturvidenskab - således blevet rettet mod Grundtvig. Kofoeds speciale er blevet til i denne frodige og inspirerende periode. I 1954 blev det udgivet af Grundtvig-Selskabet under titlen Grundtvig som selvbiograf.

Også mht. valget af specialets særlige emne var Kofoed ifølge bogens forord inspireret af Ejnar Thomsen. Vigtigere end baggrunden er imidlertid Kofoeds behandling af emnet. Under omtale af Grundtvigs ungdomsår havde ældre monografier ofte anvendt udtalelser fra langt senere perioder til at udfylde de "huller", der ikke dækkedes af dagbøger, breve og andre samtidige kilder. Herved fremkom et fortegnet billede præget af Grundtvigs senere udvikling. For at rette op på dette misforhold valgte Kofoed udelukkende at arbejde med tekster, der stammer fra samme periode. Endvidere valgte han med klogt mådehold at begrænse sin undersøgelse til årene 1800-1810 og herunder at inddrage det omfattende utrykte materiale, der forefindes i Grundtvig-arkivet på Det Kongelige Bibliotek.

Inden for den nævnte tidsramme 1800-1810 koncentreredes Kofoeds undersøgelse om tre faser: (a) Grundtvigs skoletid og studenterår, (b) Egelykke-tiden og (c) omvendelseskrisen i 1810. Første afsnit, der i udstrakt grad støtter sig til Albecks og Scharlings undersøgelser, bringer ikke noget væsentligt nyt. Helt anderledes forholder det sig mht. andet afsnit. Adskilligt materiale, som på det tidspunkt var ukendt, fremdrages, og en række omdiskuterede problemer drøftes. Hvad angår forelskelsen i Constance, lægger han vægt på Grundtvigs ensomhedsfølelse som baggrund for hans betagelse af fruen, og udviklingen i forholdet belyses ved hidtil ukendte tekster. Endvidere må man fremhæve et afsnit, der behandler Grundtvigs opfattelse af mytologi og kristendom. Som baggrund for de velkendte og omdiskuterede linjer fra 1808: "Høje Odin, hvide Krist! / Slettet ud er Eders Tvist, / Begge sønner af Alfader” kunne Kofoed henvise til et materiale, hvoraf fremgår, at Grundtvig på det pågældende tidspunkt tilsluttede sig tanken om en urmonoteisme, dvs. at nordisk asatro og kristendom hvilede på samme åbenbaringsgrundlag.

Det sidste afsnit omhandler Grundtvigs dybtgående krise i 1810-11. Utvivlsomt med rette betoner Kofoed et tidligere undervurderet moment: misforholdet til forældrene. Tidligere behandlinger af emnet havde været tilbøjelige til at tolke begivenheden som udslag af filosofiske og teologiske spekulationer og/eller af en maniodepressiv psykose. Sådanne forhold kan 
selvsagt have haft deres betydning. Forholdet til forældrene har imidlertid spillet en lige så stor rolle. På dette punkt foregriber Kofoed senere forsknings fokusering på netop dette forhold, jf. f.eks. de omfattende studier fremlagt af den amerikanske forsker Gerald M. Haslam: N.F.S. Grundtvigs Fadrenearv (1998).

Trods sit beskedne omfang (136 sider) er Kofoeds bog vigtig. Den er et vidnesbyrd om den inspirerende periode, i hvilken den blev til. Meget dengang ukendt materiale blev her fremdraget og indarbejdet. Den bidrog til drøftelsen af problemer, der både før og siden har været aktuelle i forskningen, og er således et perspektivrigt arbejde.

I de nærmest følgende år blev Kofoed inddraget i arbejdet med den store Registrant over N.F.S. Grundtvigs Papirer I-XXX, der udkom i 195764 udgivet i samarbejde mellem Grundtvig-Selskabet og Det Danske Sprog- og Litteraturselskab. Opgaven var først så nøjagtigt som muligt at bestemme hvert enkelt manuskripts datering og at udarbejde en kortfattet indholdsbeskrivelse. Derpå skulle anføres eventuelle tidligere tryk og benyttelse samt det eventuelle nummer i Steen Johansens bibliografi. Kofoeds bidrag, der findes i bindene XXI-XXII og XXV, behandler ældre og senere digte foruden materiale fra Langelandstiden. Da hver enkelt ark er nøje dateret, kan det fastslås, at Kofoed udførte dette arbejde i tiden fra marts 1955 til januar 1960, altså i perioder, hvor han ikke var optaget af sin funktion som dansk lektor i Sverige. Arbejdet var af varierende sværhedsgrad. Enkelte manuskripter kunne være lette at registrere, andre ikke. Undertiden kunne det tage flere dage at fastslå manuskriptets datering eller at tyde vanskelige passager. Som den yngste af de i alt otte registratorer udførte Kofoed dermed et arbejde, der fik blivende betydning for Grundtvigforskningen.

Da Kofoed sigtede mod en universitetsansættelse inden for dansk litteratur, skønnede han det nødvendigt at udvide sine kompetencer. I de nærmest følgende år koncentrerede han sig derfor om H.C. Andersens forfatterskab. Disputatsen Studier i H.C. Andersens Fortallekunst forsvaredes ved Århus Universitet den 18. februar 1967. Officielle opponenter var H.C. Andersen-eksperten, overbibliotekar, dr.phil. H. Topsøe-Jensen og professor, dr.phil. Gustav Albeck. I disputatsen omtales Grundtvig kun ganske få gange. Men Grundtvig var dog på ingen måde gemt og glemt. I flere udgivelser fra de følgende år spiller Grundtvig en ganske betydelig rolle. I Myte og intellekt (1968) tolkes Grundtvig og Kierkegaard i lyset af 
Jungs psykologiske teorier, jf. William Michelsens anmeldelse i Grundtvig-Studier (1970).

I Kofoeds Litterare skabnetydninger (1989) får Grundtvig tildelt 30 sider og i det noget større værk Grundtrak af en europaisk poetik (1994) et af bogens 11 kapitler. Også den omstændighed, at Kofoed i en årrække var formand for Ingemann-Selskabet, gav anledning til ny beskæftigelse med Grundtvigs liv og forfatterskab. I Kofoeds bog Et livsvarigt venskab (1992), der handler om venskabet mellem H.C. Andersen og B.S. Ingemann, er Grundtvig nævnt flere gange. Bl.a. oplyses, at Andersen i sin "Levnedsbog" fra 1832 skriver, at Ingemann mht. "finanser" gav ham "nogen hjælp ... hvortil Grundtvig bidrog” (s. 13). Oplysningen overrasker. På det tidspunkt var Grundtvig uden embede. I et brev til J.C. Lindberg fra 1833 udtrykker han en bevæget glæde over i fødselsdagsgave at have modtaget en pokal, der indeholdt "en Rulle Danske Ducater" (Breve II, 226).

Endelig må nævnes en udgivelse, som de færreste er opmærksomme på. Det drejer sig om Kofoeds bidrag til fejringen af Grundtvigjubilæet i 1983. I anledning af jubilæet udgav Københavns Dag- og Aftenseminarium i 1984 et fotokopieret festskrift under titlen Kalejdoskop. Hertil har Kofoed bidraget med en afhandling om "Grundtvig som mytolog og historiker" (s. 5-36). At skriftet er udgivet i pædagogisk sammenhæng med henblik på undervisning, fremgår bl.a. af de mange illustrationer, hvoraf nogle f.eks. tegningerne af Axel Olrik - er velkendte, andre ikke. Afhandlingen er tilgængelig på Grundtvig-Biblioteket i Vartov.

Afsluttende kan det fastslås, at Kofoed så vist ikke gemte eller glemte Grundtvig. Tværtimod. Der var tale om "et livsvarigt venskab" - for nu at gentage titlen på en af hans bøger. 